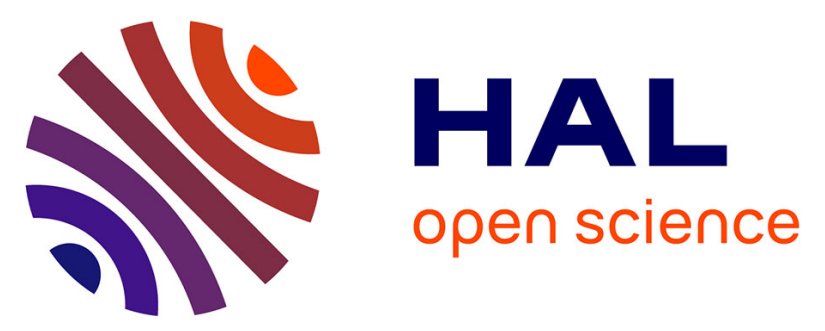

\title{
Effects of LHRH and LHRH-A on plasma GtH levels and maturation/ovulation in the common carp, Cyprinus carpio, kept under various environmental conditions
} Roland Billard, K. Bieniarz, R.E. Peter, M. Sokolowka, Claudine Weil, L.W. Crim

\section{To cite this version:}

Roland Billard, K. Bieniarz, R.E. Peter, M. Sokolowka, Claudine Weil, et al.. Effects of LHRH and LHRH-A on plasma GtH levels and maturation/ovulation in the common carp, Cyprinus carpio, kept under various environmental conditions. Aquaculture, 1984, 41 (3), pp.245-254. 10.1016/00448486(84)90287-4 . hal-01601075

\section{HAL Id: hal-01601075 \\ https://hal.science/hal-01601075}

Submitted on 2 Jun 2020

HAL is a multi-disciplinary open access archive for the deposit and dissemination of scientific research documents, whether they are published or not. The documents may come from teaching and research institutions in France or abroad, or from public or private research centers.
L'archive ouverte pluridisciplinaire HAL, est destinée au dépôt et à la diffusion de documents scientifiques de niveau recherche, publiés ou non, émanant des établissements d'enseignement et de recherche français ou étrangers, des laboratoires publics ou privés.

\section{다(1)(2)}

Distributed under a Creative Commons Attribution - ShareAlikel 4.0 International 


\title{
EFFECTS OF LHRH AND LHRH-A ON PLASMA GtH LEVELS AND MATURATION/OVULATION IN THE COMMON CARP, CYPRINUS CARPIO, KEPT UNDER VARIOUS ENVIRONMENTAL CONDITIONS
}

\author{
R. BILLARD ${ }^{1}$, K. BIENIARZ ${ }^{2}$, R.E. PETER ${ }^{3}$, M. SOKOLOWKA $^{2,3}$, C. WEIL $^{1}$ and \\ L.W. CRIM ${ }^{4}$ \\ 'Station de Physiologie Animale et Laboratoire de Physiologie des Poissons, I.N.R.A., \\ 78350 Jouy-en-Josas et Campus de Beaulieu, 35042 Rennes (France) \\ ${ }^{2}$ Academy of Agriculture, Department of Ichthyobiology and Fisheries, ul. I. Ambrozowa \\ 6, 30-149 Krakow-Mydlniki (Poland) \\ ${ }^{3}$ Department of Zoology, University of Alberta, Edmonton, Alberta T6G 2E9 (Canada) \\ ${ }^{4}$ Marine Sciences Research Laboratory, Memorial University of Newfoundland, St. John's, \\ Newfoundland A1C 5S7 (Canada)
}

(Accepted 30 March 1984)

\section{ABSTRACT}

Billard, R., Bieniarz, K., Peter, R.E., Sokolowka, M., Weil, C. and Crim, L.W., 1984. Effects of LHRH and LHRH-A on plasma GtH levels and maturation/ovulation in the common carp, Cyprinus carpio, kept under various environmental conditions. Aquaculture, 41: 245-254.

Experiments were carried out to determine if some environmental factors usually present in spawning ponds at the time of ovulation could potentiate the effects of LHRH or LHRH-A on the plasma level of GtH, ocyte maturation or ovulation in the common carp, Cyprinus carpio. In one experiment females were held in the absence of a male in cages placed in rearing ponds containing a dense population of unicellular algae; the cages touched the bottom but there was no vegetation inside the cages. When LHRH-A was given in two injections (the first $5 \mu \mathrm{g} / \mathrm{kg}$, the second, $6 \mathrm{~h}$ later, $50 \mu \mathrm{g} / \mathrm{kg}$ ) plasma $\mathrm{GtH}$ was increased and followed oocyte maturation. Ovulation occurred in $50 \%$ (3 of 6) of the females. In another experiment, using a similar LHRH-A treatment schedule, the females were held in aquaria with added vegetation to serve as a spawning substrate; in such a simplified environment the effect of LHRH-A was not potentiated. Similarly, the natural environment of spawning ponds including the presence of males was of no benefit to the response to low doses of LHRH or LHRH-A when the water temperature was low $\left(12^{\circ} \mathrm{C}\right)$. These results suggest that some undetermined environmental factors besides vegetation present in a pond situation may potentiate the effect of LHRH-A, possibly via abatement of the action of an endogenous gonadotropin release-inhibitory factor.

\section{INTRODUCTION}

Vegetation and photoperiod are environmental factors used as cues for synchronization of spontaneous ovulation in goldfish (Stacey et al., 1979a,b). A similar situation may exist in common carp since females placed in spawning 
ponds early in the day usually undergo ovulation at night and spawning at dawn (unpublished observations).

Peter et al. (1978) and Peter and Paulencu (1980) proposed, on the basis of brain lesioning studies, that a gonadotropin release-inhibitory factor (GRIF) is present in goldfish that modulates the responsiveness to gonadotropin-releasing hormone, and inhibits spontaneous release of gonadotropin $(\mathrm{GtH})$. Brain lesioning studies on common carp indicate that GRIF is present in this species as well (unpublished results). Dopamine has been shown to have GRIF activity in goldfish (Chang et al., 1983; Chang and Peter, 1983a). Furthermore, blocking the action of dopamine on the pituitary by injection of the antagonist pimozide greatly potentiates the $\mathrm{GtH}$ release-response to des $\mathrm{Gly}^{10}\left[\mathrm{D}-\mathrm{Ala}^{6}\right]$ luteinizing hormone-releasing hormone ethylamide (LHRH-A) in goldfish (Chang and Peter, 1983a; Sokolowska et al., 1984) and common carp (Billard et al., 1983) held in aquaria; this combined treatment is highly effective for inducing ovulation in goldfish and is quite effective for common carp.

Weil et al. (1980) injected low dosages of luteinizing hormone-releasing hormone (LHRH) intravenously into gravid common carp, and, although plasma gonadotropin levels were increased and germinal vesicle migration induced in oocytes, ovulation did not occur. Similarly, Sokolowska (1982) found increased plasma GtH levels and oocyte maturation in carp following intrapituitary or intracardiac injection of LHRH, but no ovulation. These experiments were done with fish held in cement aquaria, and it is not known whether provision of certain environmental conditions, such as vegetation (as a potential spawning substrate) or pond water, may sensitize carp to injection of LHRH or LHRH-A due to natural abatement of GRIF. Peter (1980) found that two injections of LHRH-A were more effective in stimulating GtH release in male goldfish than a single injection of a larger dosage, indicating that self-potentiation of action of LHRH-A can be an important factor in the magnitude of the GtH release-response. The effects of pairs of injections of LHRH but not LHRH-A were tested on GtH release, oocyte maturation and ovulation in carp (Weil et al., 1980). Carp with oocytes in an advanced stage of maturation were more responsive, in terms of advancing oocyte maturation further, to an intrapituitary injection of LHRH than carp with oocytes in early stages of maturation (Sokolowska et al., 1978). However, there is no information available on the influence of the stage of oocyte maturation in carp on the responsiveness to intraperitoneal or intravenous injection of LHRH or LHRH-A. The present investigation is an attempt to address these various questions.

\section{MATERIALS AND METHODS}

Experiments were carried out on 4-year-old common carp, Cyprinus carpio L., mirror variety, of $3-6 \mathrm{~kg}$ body weight, at Mydlniki or Zator, Poland. The fish were held in outside ponds until captured just prior to the experiments. 
Experiment I. Effects of LHRH and LHRH-A on oocyte maturation in females held in concrete, ceramic-lined aquaria or in spawning ponds (28 June-2 July 1980)

Thirty females were selected for each location. In each case, 10 fish were injected with $0.7 \% 0 \mathrm{NaCl}, 10$ with $1 \mu \mathrm{g} \mathrm{LHRH} / \mathrm{kg}$ and 10 with $1 \mu \mathrm{g} \mathrm{LHRH}$ $\mathrm{A} / \mathrm{kg}$. LHRH and LHRH-A were purchased from Sigma. The temperature in the flow-through aquaria $\left(2 \mathrm{~m}^{3}\right)$ was regulated to $18-20^{\circ} \mathrm{C}$, and a simulated natural photoperiod was provided. Temperature in the Dubish-style ponds at the onset of the experiment was $18^{\circ} \mathrm{C}$, but decreased and remained at $12^{\circ} \mathrm{C}$ one day after injection, due to overcast weather. In addition, 4 males were added to each group of 10 females in the outside ponds. Injections were given intracardially (IC) at $10.00 \mathrm{~h}$. Ovarian biopsies were taken, as described by Bieniarz and Epler (1976), immediately before the injections and 4 days later. Ovarian samples were fixed in Serra's solution, cleared in turpentine, and oocytes were classified according to the following scale: Stage 1: germinal vesicle (GV) in the centre of the oocyte or slightly off centre;

Stage 2: GV shifted toward the periphery but not touching the membrane; Stage 3: GV contacting the membrane;

Stage 4: GV breakdown (GVBD).

Experiment II. Effects of a pair of injections of LHRH-A on oocyte maturation in females held in aquaria, with or without vegetation (29 April-1 May 1982)

The same aquaria were used as in Experiment I. Four groups of 8 females were formed; 2 groups were given saline and 2 groups were given LHRH-A as two intraperitoneal (IP) injections $6 \mathrm{~h}$ apart, the first at $5 \mu \mathrm{g} / \mathrm{kg}$ and the second at $50 \mu \mathrm{g} / \mathrm{kg}$. Injections of saline and LHRH-A were at $14.00 \mathrm{~h}$ and $20.00 \mathrm{~h}$. Earlier in the day $(07.00 \mathrm{~h})$, vegetation, freshly cut from spawning ponds, was added to the aquaria containing a control and an LHRH-A group, sufficient to make a floating mat over the entire surface. Blood samples were taken from the caudal vasculature using heparinized syringes before the first injection, $6 \mathrm{~h}$ later at the time of the second injection, and at 19,30 and $43 \mathrm{~h}$ after the first injection. Plasma was stored at $-20^{\circ} \mathrm{C}$ and $\mathrm{GtH}$ was determined later by radioimmunoassay (Breton et al., 1974). Ovarian samples were taken, as in Experiment I, before the first injection and at 19,30 and $43 \mathrm{~h}$ later. The experiment was carried out at $18-20^{\circ} \mathrm{C}$.

Experiment III. Effects of a pair of injections of LHRH-A on oocyte maturation in females caged in a rearing pond (2-4 June 1981)

A saline injected group $(N=9)$ and an LHRH-A injected group $(N=6)$ were placed in separate cages in a large pond. The cages touched the bottom 
and each enclosed approximately $6 \mathrm{~m}^{3}$ of water; no vegetation was present inside or near the outside of the cages and the temperature was $18-20^{\circ} \mathrm{C}$ throughout the experiment. As in Experiment II, the saline and LHRH-A groups were given two injections $6 \mathrm{~h}$ apart (first injection at $13.00 \mathrm{~h}$ ); the dosages of LHRH-A were the same as in Experiment II. Blood samples were taken before the first and second injections, and at 19,30 and $43 \mathrm{~h}$ after the first injection. Ovarian samples were taken, as in Experiment I, before the first injection and at 19 and $53 \mathrm{~h}$ after the first injection.

\section{Statistics}

Data are presented as $\bar{x} \pm \mathrm{SE}$. Students $t$ test was used to compare differences in plasma GtH levels between groups. Analysis of variance was used to compare the differences between groups in stages of oocyte maturation.

\section{RESULTS}

Experiment I. Effects of LHRH and LHRH-A on oocyte maturation in females held in aquaria or in spawning ponds

In the fish held in the aquaria, we found that a decrease in the number of oocytes in stage 1 and an increase in the percentages in stages 2 and 3 occurred in all the groups during the 4-day duration of the experiment. No change in the proportion of oocytes showing GVBD was found in any group.

The fish held in the ponds following injection had similar percentages of oocyte stages at the start of the experiment as the fish held in aquaria. However, no significant changes in oocyte maturation stages occurred during the experiment in the fish held in ponds (data not shown).

\section{Experiment II. Effects of injections of LHRH-A on oocyte maturation in females held in aquaria, with or without vegetation}

Most oocytes in the two groups of females injected with LHRH-A reached stages 3 or 4 of oocyte maturation by the end of the experiment; however, no ovulations occurred (Fig. 1). The two saline-injected control groups showed no changes in oocyte condition. There were no significant changes in plasma GtH levels in the control groups throughout the experiments (Fig. 2). Both groups injected with LHRH-A showed significant increases in plasma GtH levels, and, although the group exposed to vegetation had somewhat higher GtH levels, there were no significant differences between the groups. 


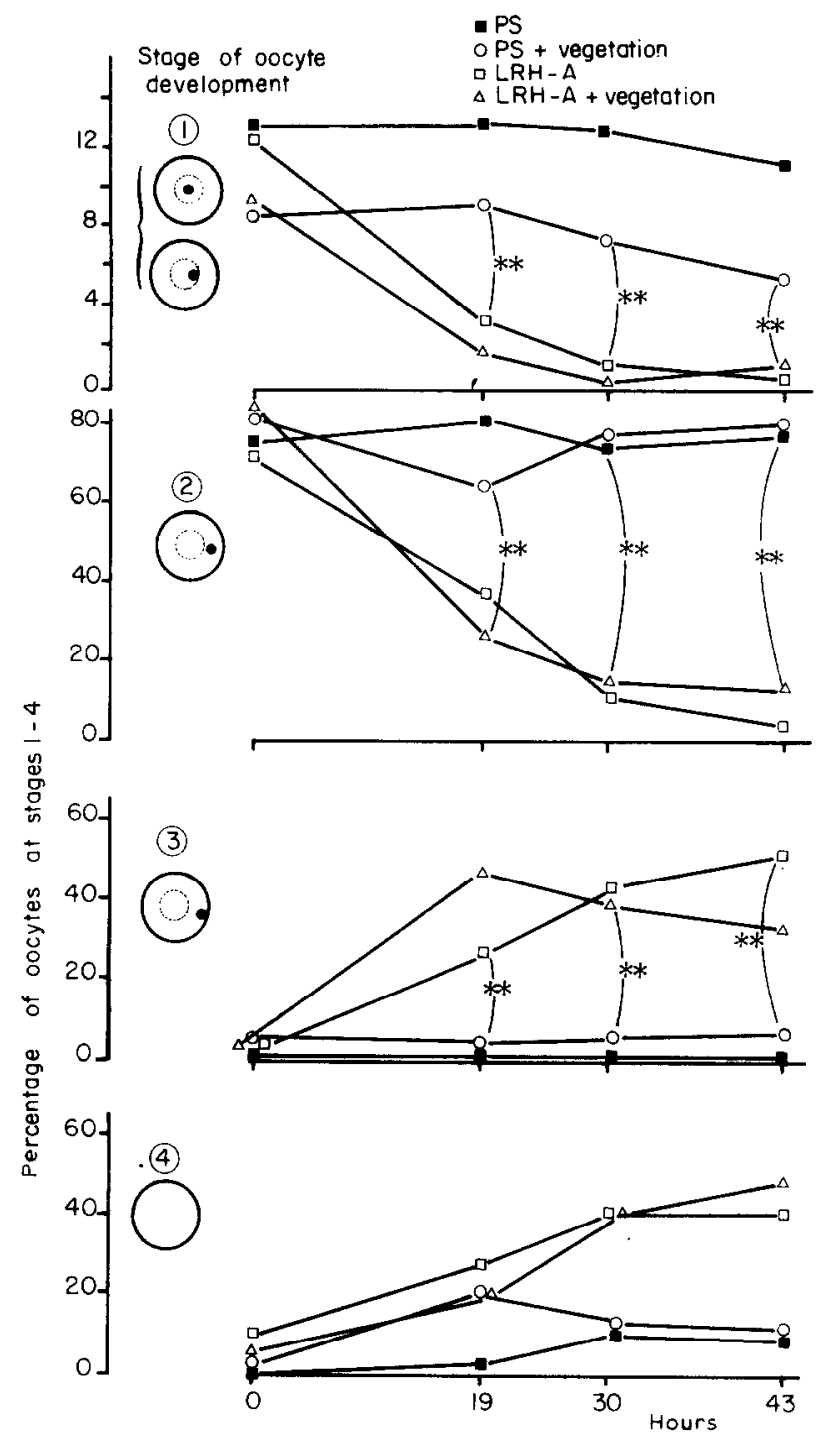

Fig. 1. The percentage of oocytes at various stages of maturation found in the ovary at 19,30 and $43 \mathrm{~h}$ after the beginning of treatment (floating vegetation added or not into the aquaria). PS: Physiological saline. $* * P<0.01$.

Experiment III. Effects of injections of LHRH-A on oocyte maturation in females caged in a pond

As shown in Fig. 3, oocytes in the saline-injected controls did not change from stages 1 or 2 during the experiment. Three LHRH-A injected fish partially ovulated (approximately 100 ovulated oocytes expressable from 


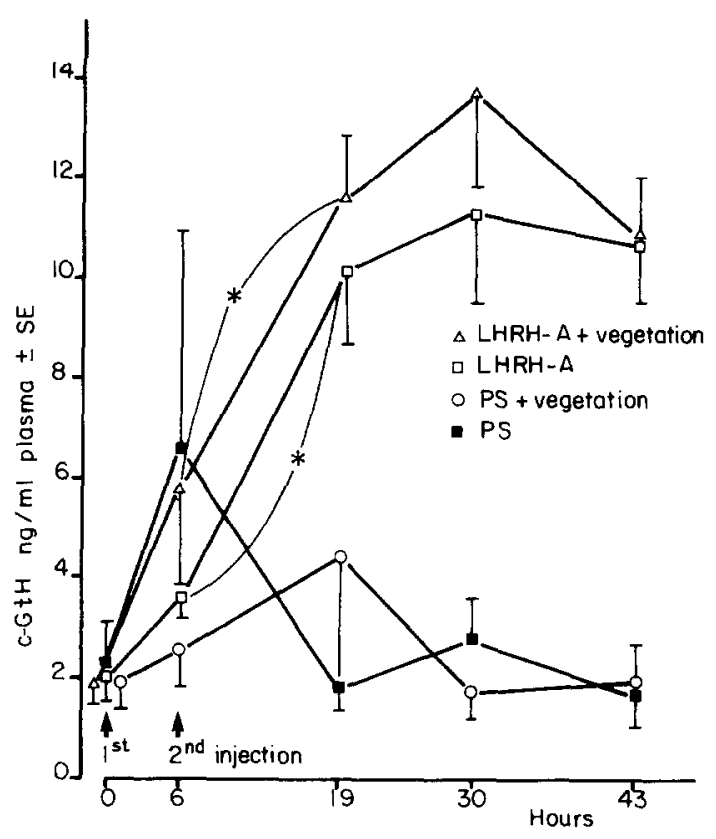

Fig. 2. The pattern of GtH after injection of LHRH-A or saline into female carp held in aquaria with or without floating vegetation. ${ }^{*} P<0.05$.

one fish, and ovulated oocytes equivalent to $7.5 \%$ and $12 \%$ of the total body weight in the two other fish): the oocyte stages and plasma GtH levels of these fish are presented separately from the non-ovulated LHRH-A treated fish (Figs. 3 and 4). Notably, a large proportion of oocytes reached stage 4 (GVBD) by $24 \mathrm{~h}$ after injection in the ovulated fish, whereas the proportion of oocytes with GVBD was not found to increase in the nonovulated LHRH-A treated fish. Plasma GtH levels in the ovulated and nonovulated LHRH-A injected fish were significantly higher than in the salineinjected controls at 6,18 and $39 \mathrm{~h}$ after the first injection, but only the nonovulated LHRH-A group was significantly higher at $53 \mathrm{~h}$. There were no significant differences in plasma GtH levels between the two sub-groups of LHRH-A injected fish, although the GtH in the ovulated fish tended to be significantly higher at $18 \mathrm{~h}$. As indicated by the large SE values, the GtH release-response to LHRH-A injection was highly variable. Notably, how-

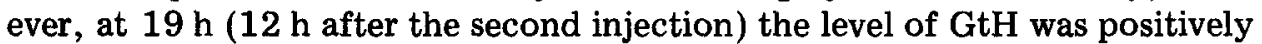
correlated $(r=0.863, P<0.05)$ with the stage of oocyte development at that time, but not at the time of injection.

\section{DISCUSSION}

The present work indicates that the effects of IP injection of LHRH-A on $\mathrm{GtH}$ release and oocyte maturation in common carp were not potentiated 


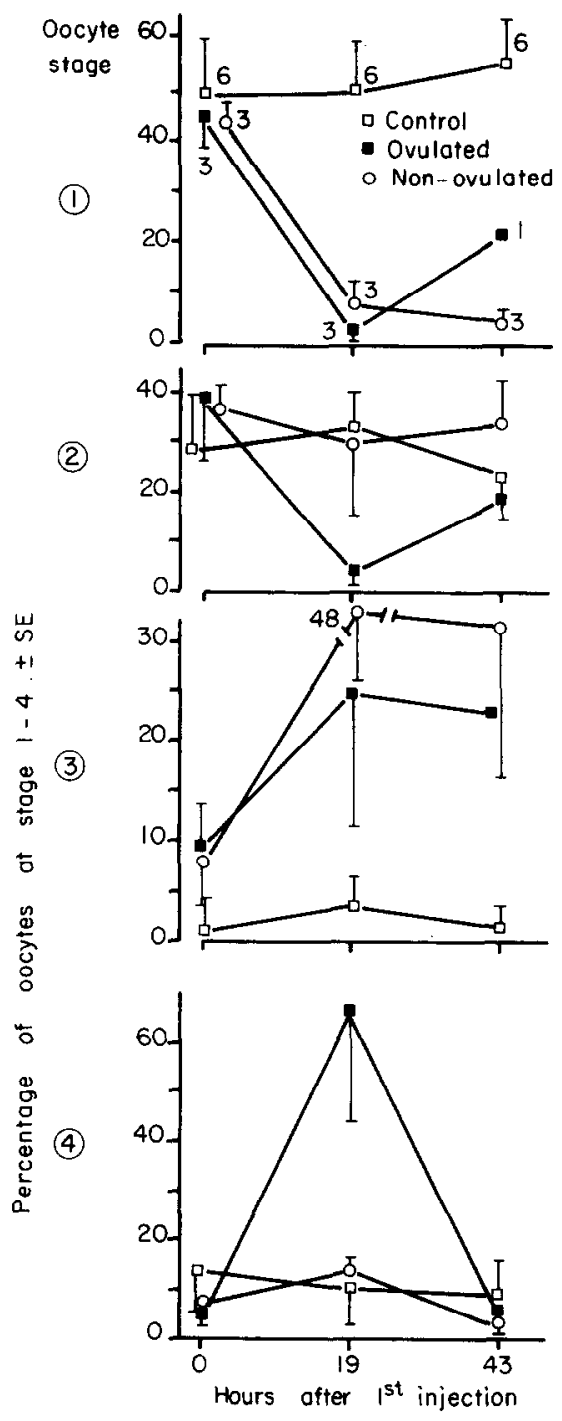

Fig. 3. Changes in the percentage of oocyte types at various stages of oocyte maturation ( 1 to 4 , see Fig. 1) in female carp caged in ponds and receiving 2 injections of LHRH-A ( 5 and $50 \mu \mathrm{g} / \mathrm{kg}$ body weight) $6 \mathrm{~h}$ apart.

when vegetation, to serve as spawning substrate, was added to the aquaria containing the injected fish. In another experiment, when similar dosages of LHRH-A were given on the same injection schedule (1st injection $5 \mu \mathrm{g} / \mathrm{kg}$; 2nd injection, $6 \mathrm{~h}$ later, $50 \mu \mathrm{g} / \mathrm{kg}$ ) to females held in cages in rearing ponds, plasma GtH levels reached a higher level and ovulation occurred in some fish (3 out of 6 ). This suggests that some environmental conditions provided by the pond situation may influence the response to LHRH-A, presumably due to abatement of the action of endogenous GRIF. However, provision 


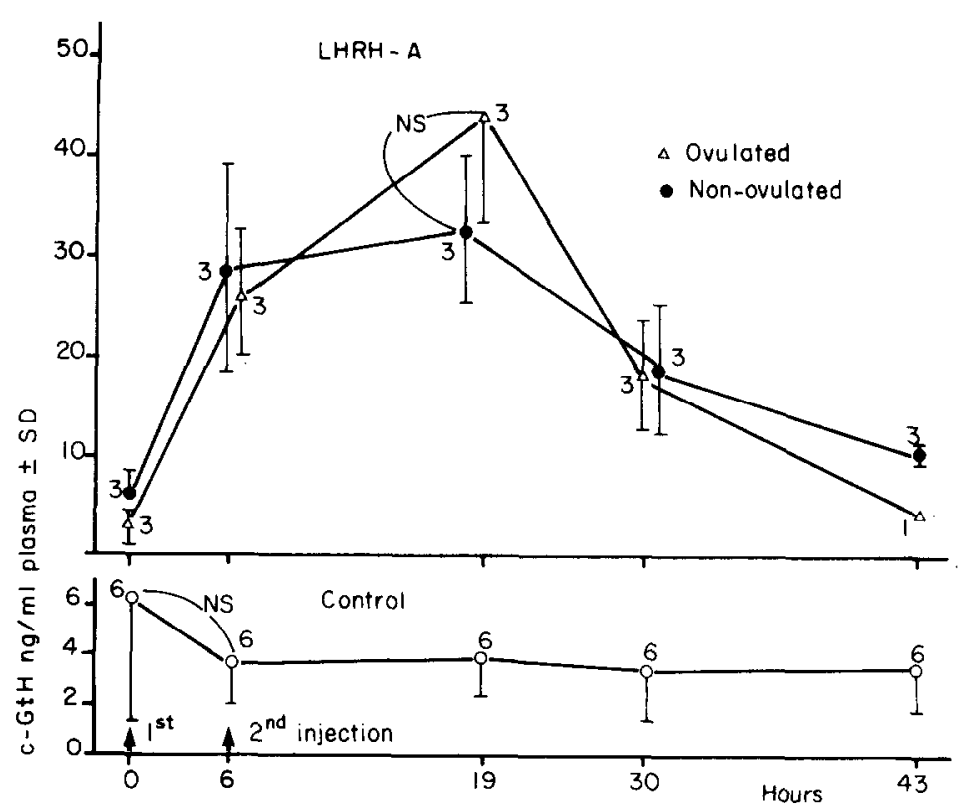

Fig. 4. Plasma c-GtH profile in ovulated and non-ovulated carp receiving 2 injections of saline or LHRH-A ( 5 and $50 \mu \mathrm{g} / \mathrm{kg}$ body weight) $6 \mathrm{~h}$ apart.

of the natural pond conditions, including the presence of males, was of no benefit to the response to a low IC dose of LHRH or LHRH-A when the temperature was low $\left(12^{\circ} \mathrm{C}\right)$ relative to the usual pond temperature for spontaneous ovulation and spawning (circa $20^{\circ} \mathrm{C}$ ).

Although the present study suggests that environmental conditions may influence the responsiveness to LHRH-A, we are not able to provide a precise definition of what those conditions are. The cage conditions in the rearing pond were without vegetation (to serve as a spawning substrate) and males (as social stimulus). However, since the pond water was rich in algae, the circadian changes in dissolved $\mathrm{O}_{2}$ and $\mathrm{CO}_{2}$, and $\mathrm{pH}$ normally found in spawning ponds (Lukowicz, 1982) were present. Additional studies are necessary to clarify this situation.

On the basis of the present study, self-potentialization of the effects of LHRH-A, by administration of a priming dose, may be important for inducing ovulation in common carp. In Experiments II and III the increase in plasma GtH levels after the first injection of LHRH-A was of the same amplitude as the increase after the second injection, although the latter dosage was ten times greater than the first. Using repeated injections of LHRH or LHRH-A (2 and $0.3 \mu \mathrm{g} / \mathrm{kg}$, respectively), Breton et al. (1983) increased the plasma GtH level of common carp up to $30 \mathrm{ng} / \mathrm{ml}$, leading to GVBD but not ovulation. Similarly, Weil et al. (1980) found germinal vesicle migration and $20 \mathrm{ng} / \mathrm{ml}$ of plasma GtH in common carp after two injections of LHRH $(3 \mu \mathrm{g} / \mathrm{kg})$. It seems, therefore, that repeated injections 
of LHRH or LHRH-A will induce an increase in plasma GtH levels sufficient to induce GVBD, but inducing ovulation is much more difficult. On the other hand, a single injection of LHRH-A alone can also induce a significant increase in germinal vesicle migration and GVBD in common carp (Billard et al., 1983).

The critical level of plasma GtH, and the length of time that this level must be maintained, for inducing ovulation in common carp are difficult to assess from available information. In Experiment III, the plasma GtH levels in ovulated fish ranged from 20 to $58 \mathrm{ng} / \mathrm{ml}$ between 6 to $18 \mathrm{~h}$ after the first injection of LHRH-A, but the mean levels in the ovulated fish were not significantly different from the levels in the non-ovulated LHRH-A treated fish. Plasma GtH levels in common carp undergoing spontaneous ovulation range from $28 \mathrm{ng} / \mathrm{ml}$ (unpublished results), to $200-300 \mathrm{ng} / \mathrm{ml}$ (Fish Reproductive Physiology Research Group and Peptide Hormone Group, 1978); following hypophysation to induce ovulation, plasma GtH levels ranged from 100 to $250 \mathrm{ng} / \mathrm{ml}$ (Jalabert et al., 1977; Bieniarz et al., 1980). Chang and Peter (1983b) suggested that in goldfish a rapid, rather than a gradual, increase to a certain critical level of GtH in the blood must occur to induce ovulation. Whether this is the case in common carp is not known.

Possible variability in the responsiveness of the ovary to GtH is another unknown factor to be considered. In the present study, there was no correlation between the position of the germinal vesicle and the degree of response in the ovary to the injection of LHRH-A, although there was a positive correlation between the tendency toward oocyte maturation and plasma GtH level. Brzuska and Bieniarz (1977) also found that the female carp which exhibit a migration of the germinal vesicle after priming with pituitary extract are usually sensitive to further hypophysation and ovulate after the second injection. On the basis of available data it is not yet possible to distinguish a responsive from a non-responsive ovary by the position of the germinal vesicle prior to the injection of LHRH-A or pituitary extract.

\section{ACKNOWLEDGEMENTS}

This work was supported by an International Grant from INRA to R.B., by the Polish-French Scientific Exchange Program, and by grants from the Natural Sciences and Engineering Research Council of Canada to R.E.P. and L.W.C.

\section{REFERENCES}

Bieniarz, K. and Epler, P., 1976. Primary results of the in vivo studies on ovarian resorption in carp, Cyrpinus carpio L. J. Fish Biol., 8: 449-451.

Bieniarz, K., Epler, P., Thuy, T.N. and Breton, B., 1980. Changes in blood gonadotropin level in mature female carp following hypophysial homogenate injections. Aquaculture, 20:65-69. 
Billard, R., Alagarswami, K., Peter, R.E. and Breton, B., 1983. Potentialisation par le pimozide des effets du LHRH-A sur la secretion gonadotrope hypophysaire, l'ovulation et la spermiation chez le carpe commune (Cyprinus carpio). C.R. Acad. Sci, Paris, 296: 181-184.

Breton, B., Kann, G., Burzawa-Gerard, E. and Billard, R., 1974. Dosage radioimmunologique d'une hormone gonadotrope de carpe (Cyprinus carpio L.). C.R. Acad. Sci. Paris, 272: 1515-1517.

Breton, B., Jalabert, B., Bieniarz, K., Sokolowska, M. and Epler, P., 1983. Effects of synthetic LH-RH and analog on plasma gonadotropin levels and maturational response to $17 \alpha$-hydroxy-20 $\beta$-dihydroprogesterone. Aquaculture, 32:105-114.

Brzuska, E. and Bieniarz, K., 1977. Determination of the stage of maturity of female carp in relation with injection of carp pituitary homogenates. Inst. Rybactwa Srodladowego, $105: 1-26$ (in Polish).

Chang, J.P. and Peter, R.E., 1983a. Effects of dopamine on gonadotropin release in female goldfish, Carassius auratus. Neuroendocrinology, $36: 351-357$.

Chang, J.P. and Peter, R.E., 1983b. Effects of pimozide and des-Gly ${ }^{10} \cdot\left[\mathrm{D}-\mathrm{Ala}^{6}\right]$ luteinizing hormone-releasing hormone ethylamide on serum gonadotropin concentrations, germinal vesicle migration and ovulation in female goldfish, Carassius auratus. Gen. Comp. Endocrinol. (in press).

Chang, J.P., Cook, A.F. and Peter, R.E., 1983. Influences of catecholamines on gonadotropin secretion in goldfish, Carassius auratus. Gen. Comp. Endocrinol., 49: 22-31.

Fish Reproductive Physiology Research Group and Peptide Hormone Group, 1978. Radioimmunoassay on serum gonadotropin of carp (Cyprinus carpio L.). Acta Biochem. Biophys. Sinica, 10:399-407.

Jalabert, B., Breton, B., Brzuska, E., Fostier, A. and Wieniawski, J., 1977. A new tool for induced spawning: the use of $17 \alpha$-hydroxy-20 $\beta$-dihydroprogesterone to spawn carp at low temperature. Aquaculture, 10: 353-364.

Lukowicz, M.B., 1982. Intensive carp Cyprinus carpio (L.) rearing in a farm pond in southern Germany and its effects on water quality. Aquacult. Eng., 1:121-137.

Peter, R.E., 1980. Serum gonadotropin levels in mature male goldfish in response to luteinizing hormone-releasing hormone (LH-RH) and des-Gly ${ }^{10} \cdot\left[\mathrm{D}-\mathrm{Ala}^{6}\right]-\mathrm{LH}-\mathrm{RH}$ ethylamide. Can. J. Zool., 58: 1100-1104.

Peter, R.E. and Paulencu, C.R., 1980. Involvement of the preoptic region in gonadotropin release-inhibition in goldfish, Carassius auratus. Neuroendocrinology, 31: 133-141.

Peter, R.E., Crim, L.W., Goos, H.J.Th. and Crim, J.W., 1978. Lesioning studies on the gravid female goldfish: neuroendocrine regulation of ovulation. Gen. Comp. Endocrinol., 35: 391-401.

Sokolowska, M., 1982. The influence of luteinizing hormone-releasing hormone (LH$\mathrm{RH}$ ) on serum gonadotropin levels and oocyte maturation in female carp (Cyprinus carpio L.). Comp. Biochem. Physiol., 73A: 273-278.

Sokolowska, M., Popek, W. and Bieniarz, K., 1978. Synthetic releasing hormones LH/ FSH-RH and LH-RH: effect of intracerebral and intramuscular injections on female carp (Cyprinus carpio L.) maturation. Ann. Biol. Anim. Biophys., 18: 963-967.

Sokolowska, M., Peter, R.E., Nahorniak, C.S., Pan, C.H., Chang, J.P., Crim, L.W., and Weil, C., 1984. Induction of ovulation in goldfish, Carassius auratus, by pimozide and analogues of LH-RH. Aquaculture, $36: 71-83$.

Stacey, N.E., Cook, A.F. and Peter, R.E., 1979a. Ovulatory surge of gonadotropin in the goldfish, Carassius auratus. Gen. Comp. Endocrinol., 37: 246-249.

Stacey, N.E., Cook, A.F. and Peter, R.E., 1979b. Spontaneous and gonadotropin-induced ovulation in the goldfish, Carassius auratus $\mathrm{L}$ : effects of external factors. J. Fish. Biol., 15: 349-361.

Weil, C., Fostier, A., Horvath, L., Marlot, S. and Berscenyi, M., 1980. Profiles of plasma gonadotropin and $17 \beta$-estradiol in the common carp, Cyprinus carpio L., as related to spawning induced by hypophysation or LH-RH treatment. Reprod. Nutr. Dev., 20: 1041-1050. 